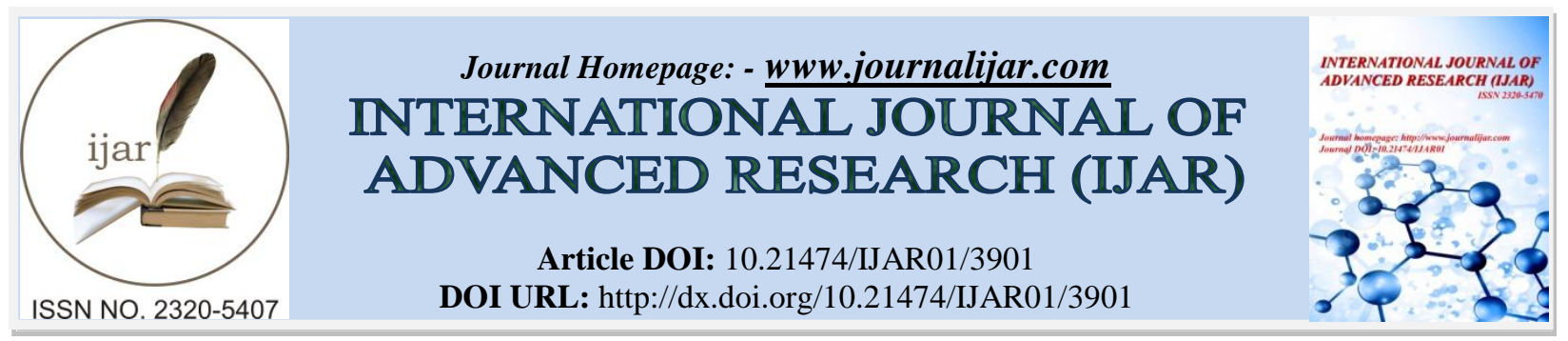

RESEARCH ARTICLE

\title{
ENHANCED BIODEGRADATION OF RED RR BY ADAPTED BACTERIAL ISOLATES.
}

\section{R. Shyamala Gowri ${ }^{1}$, P. Meenambigai ${ }^{1}$, R. Vijayaraghavan ${ }^{2}$, P. Raja Rajeswari ${ }^{1}$ and R. Vinitha ${ }^{1}$}

1. Department of Microbiology and Biochemistry, Nadar saraswathi college of Arts and Science, Theni, Tamil Nadu, India-625531.

2. Department of Biotechnology, Nehru Arts and science College, Coimbatore, Tamil Nadu, India -641105.

\section{Manuscript Info}

Manuscript History

Received: 01 February 2017

Final Accepted: 01 March 2017

Published: April 2017

Key words:-

Biodegradation, optimization, reactive dye, Red RR

\begin{abstract}
The effluents from the textile industries after dyeing process contain more amounts of organic and inorganic contaminants which cause pollution to the surrounding and it also affects the entire ecosystem. The effluent can be treated by physical, chemical and biological method. The physical and chemical method is not efficient for degradation of dye because of its increased stability, resistance of dyes for degradation, increased cost and less efficiency. The biological method is harmless one to treat the dye. The present study was carried out to determine the efficiency of degradation of dye (Red RR) by isolated bacterial strains.21 cultures were isolated from dye effluent of that, 3culture (Escherichia coli, Enterobacter aerogenes and Klebsliella variicola, ) shows maximum degradation of Red RR dye of about $98 \%$ at optimized condition, $0.01 \%$ dye concentration, $\mathrm{pH} 7$, temperature $30^{\circ} \mathrm{C}, 0.3 \%$ of maltose, $0.4 \%$ of peptone.
\end{abstract}

Copy Right, IJAR, 2017,. All rights reserved.

\section{Introduction:-}

Due to rapid industrialization and urbanization, a group of chemicals including dyes, pigments, and aromatic molecular structural compounds were extensively used in a number of industrial applications such as textiles, printing, pharmaceuticals, food, toys, paper, plastic and cosmetics (Mohana et al ., 2008). Textile industries have shown an important increase in the make use of synthetic dyes as a coloring material. The annual world production of textiles is about 30 million tones requiring 700,000 tonnes of different dyes (Zollinger., 1987). Reactive dyes are used in many textile industries because of its characteristics like bright colour, excellent color fastness and easy application on cloth ( O' Mahony et al., 2002). Reactive dyes are azo - based chromophores with different reactive functional groups. Because of its complex chemical structures, dyes are resistant to fading even it is exposed to light, water and chemicals. (Poots and Mckay., 1976).

Effluents containing reactive azo dyes from textile industries creates serious environmental pollution due to the presence of dyes in water is highly visible and affects the water transparency and aesthetics even in minute concentration of dyes. So the effluents from the textile industries should be processed before their discharge into the environment (Hao et al., 2000). Treatment of effluent that contains reactive dyes at concentration of 5-1500 mg/l from the textile industries is a primary concern in the surrounding (Lata et al., 2007). Nearly commercial dyes are there to textile industries with over 700,000 tons of dyes are produced annually. The reactive azo dyes are recalcitrant to treat the waste water, so $90 \%$ of dyes remain unaffected after activated sludge treatment.(Lucas et al., 2007). Reactive dyes forms covalent bond between the dye and the fibres, so reactive dyes hydrolyse easily resulting

Corresponding Author:- R. Shyamala Gowri.

Address:- Department of Microbiology and Biochemistry, Nadar saraswathi college of Arts and 
in a high proportion of unfixed reactive dyes, which have to be washed off during the dyeing process. Nearly $50 \%$ of initial dye will be retained in the dye bath effluent (Shore., 1995). Color is the most significant contaminant in textile waste water and it has to be removed before its release in to the receiving water bodies.

Various physical, chemical and biological techniques have been used for the processing of dye - contaminated waste water because municipal aerobic management system, based on biological activity is found as ineffective for the treatment of dyes (Moran, 1997). Most of the studies paying attention on some microorganisms which are able to biodegrade and biosorb dyes in effluent contain dyes. Algae, fungi and bacteria are proficient of decolourizing a different dyes present in the effluent. (Fu and Tirarahavan., 2004; Pazarlioglu et al., 2005)

\section{Materials and Methods:- Collection of samples:-}

Effluent Samples were obtained from profoundly dye-contaminated waste water from surrounding areas of the textile industries and waste water treatment plant in and around Coimbatore, India. Samples were collected in sterile glass - screw cap tubes and preserved at $4^{0} \mathrm{c}$ in refrigenerator for further studies.

\section{Isolation and Screening of dye degrading bacteria:-}

Isolation and screening was performed to find out the most competent bacterial isolates capable of decolourizing Red RR dye using mineral salt medium from textile dye effluent by serial dilution technique with $0.01 \%$ concentration of Red RR dye. Morphologically different colonies from the effluent were isolated by the decolourization around the isolates were inoculated in minimal salt medium and incubated at $35^{\circ} \mathrm{C}$ for 7 days. The decolourization activity was expressed in conditions of decolourization percentage of dye. Aseptically drawn aliquots was centrifuge at $10,000 . \mathrm{rpm}$ for $10 \mathrm{~min}$ and remaining dye content in the supernatant was measured at 520 $\mathrm{nm}$ using UV-Vis Spectrophotometer. All the assays were done in triplicates and uninoculated media with same concentration of dye were used as control.

Samples from experimental and control flasks were examined for degradation. The OD of the supernatant was determined with spectrophotometer at $(\lambda \max 520) . \%$ dye degradation was calculated:

$\%$ Decolorization $=\quad$ initial absorbance-final absorbance $\times 100$

Initial absorbance

\section{Phylogenetic Analysis:-}

In the phylogenetic analysis, the sequences of the 16s rRNA genes were compared against the sequence available from Gen Bank using the BLASTN program and were aligned using Clustal W software and Phylogenetic trees were constructed using the Neighbor- Joining Method.

\section{Compatibility test:-}

Compatibility test was done to determine the antagonistic effect among the selected isolates for the efficient biodegradation of Red RR dye by mixed consortium. In this method standard well - cut method was used to check the compatibility of each strain on one another. Based on the zone of clearance around the well, compatibility was assessed. The antagonistic effect of an organism was checked by using compatibility testing. Based on the zone of clearance the compatibility was determined (Rajendran et al., 2011)

\section{Optimization:-}

Various factors were optimized to achieve the highest degradation effect of Red RR by the selected isolates of bacteria.

\section{Concentration of Dye:-}

Various concentration of Red RR dye were used to find the best concentration for maximum degradation of dye. The concentration of dye supplemented in the minimal salt medium are $0.01 \%, 0.05,0.10 \%, 0.15 \%, 0.20 \%$ and incubated at $35^{\circ} \mathrm{c}$ for degradation. The degradation was examined by taking $1.5 \mathrm{ml}$ of aliquots from experimental test tubes in the effendoff and it was centrifuged at $10000 \mathrm{rpm}$ for 10 minutes to remove the cells and the absorbance of the supernatants was measured at $520 \mathrm{~nm}$ for Red RR dye using UV spectrophotometer. The uninoculated tube was used blank and to check out for decolourization by abiotic source. 
pH:-

$\mathrm{pH}$ of the medium play an important role for all the physiological and metabolic processes. The experiment was to determine the influence of $\mathrm{pH}$ on the degradation of textile dyes. Optimum $\mathrm{pH}$ for the bacteria is $\mathrm{pH}$ 7. So the minimal Salt medium with dye were adjusted to various range of $\mathrm{pH}$ such as $\mathrm{pH}$ 5,6,7,8 and 9 and inoculated with isolated strains and incubated at $35^{\circ} \mathrm{c}$. The $\mathrm{pH}$ was adjusted by using $0.01 \mathrm{M} \mathrm{HCl}$ and $0.01 \mathrm{M} \mathrm{NaoH}$ solutions.

\section{Temperature:-}

Temperature is one of the physical factor require for maximum degradation of dye. Degradation of Red RR dye by the selected bacterial isolates were studied at various temperature like $25,30,35,40$ and $45^{\circ} \mathrm{c}$. The medium used for degradation was minimal salt medium which is enriched with Red $\mathrm{RR}$ at $0.01 \%$ concentration and the $\mathrm{pH}$ of the medium is maintained at $\mathrm{pH} 7$.

\section{Carbon and Nitrogen source:-}

In order to assess the effects of different carbon and nitrogen sources on decolourization by bacteria, five carbon (glucose, sucrose, maltose, starch and fructose)and nitrogen sources (Ammonium nitrate, urea, peptone, beef extract and dipotassium nitrate) were used at the rate of $0.1-0.5 \%$. The minimal salt medium supplemented with Red RR at the concentration of $0.01 \%$ was used. After inoculation the tubes were incubated at $30^{\circ} \mathrm{c}$ for the biodegradation

\section{Biodegradation of Red RR dye by mixed consortium:-}

At optimized condition, the Red RR dye was degrade by the double and triple combination of isolated strain to find out the maximum degradation of dye than the individual strains.

\section{Statistical Analysis:-}

The statistical analysis were done from the results gained and the data have been expressed in terms of mean \pm standard error and analyzed by one-way analysis of variance and readings were considered significant when $\mathrm{P}$ was 0.05 .

\section{FTIR analysis:-}

FT-IR (Fourier Transform Infrared Spectroscopy)analysis was done by using Shimadzu 8400s spectrophotometer in the mid-infrared of 4000- $400 \mathrm{~cm}^{-1}$. The FTIR spectrum acts as a valuable analytical tool that enables the determination of both the type and Strength of interactions that occur within reactive dyes containing different functional groups after biodegradation. All samples were dried and analyzed for biodegradation

\section{Result and Discussion:-}

\section{Isolation, Screening and Identification of Red RR dye:-}

16morphologically different bacterial strains were isolated from textile effluent based on its ability to produce zone of decolourization around colonies grown on minimal agar medium containing $0.01 \%$ Red RR dye. Of these 16 cultures, 3 cultures (T2, T16 and T18) were shown efficient degradation of about98\% when compared to other isolates. The 16s rRNA gene sequence of the isolated bacterial strain were determined and compared with $16 \mathrm{~s} \mathrm{r}$ RNA gene sequences in the gen bank nucleotide database and the bacterial strains were identified as Escherichia coli, Enterobacter aerogenes, Klebsliella variicola, respectively. 
a)

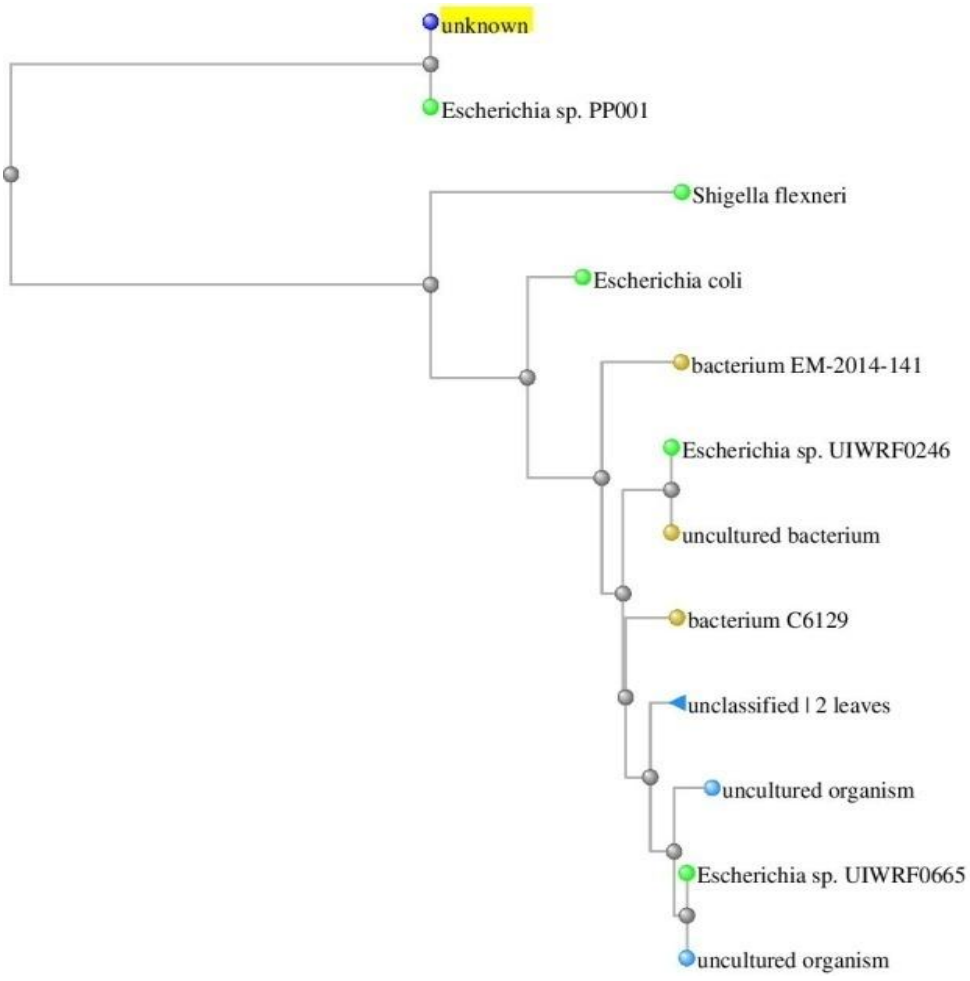

b)

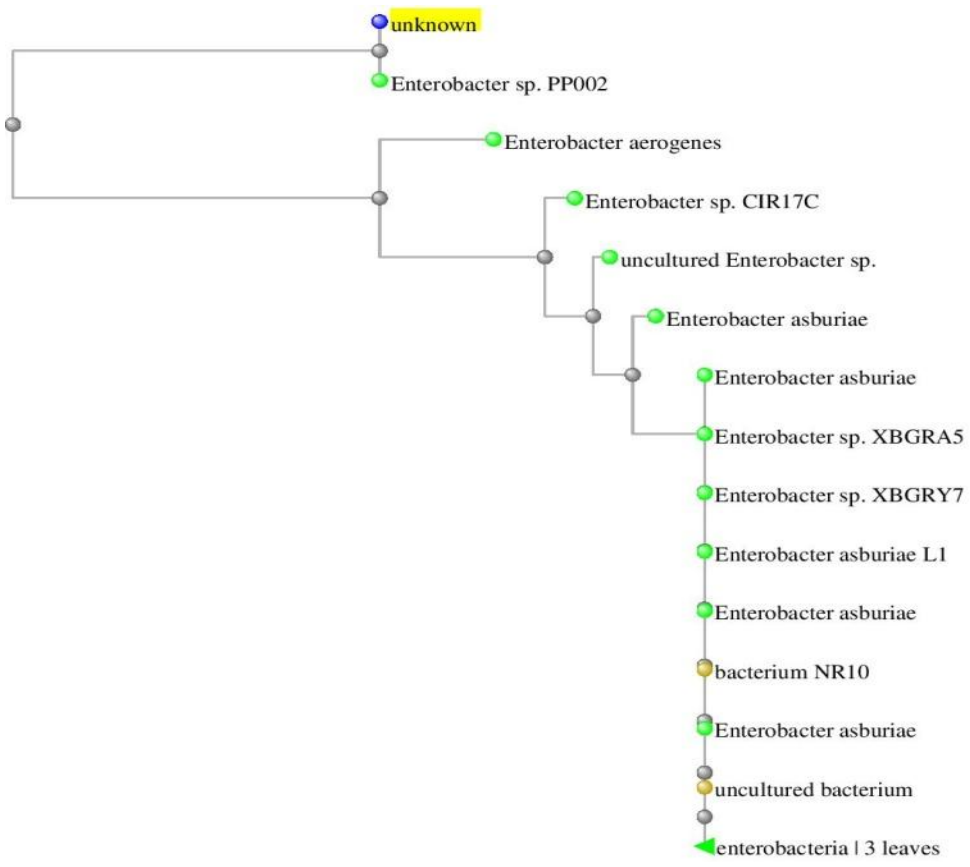

c) 


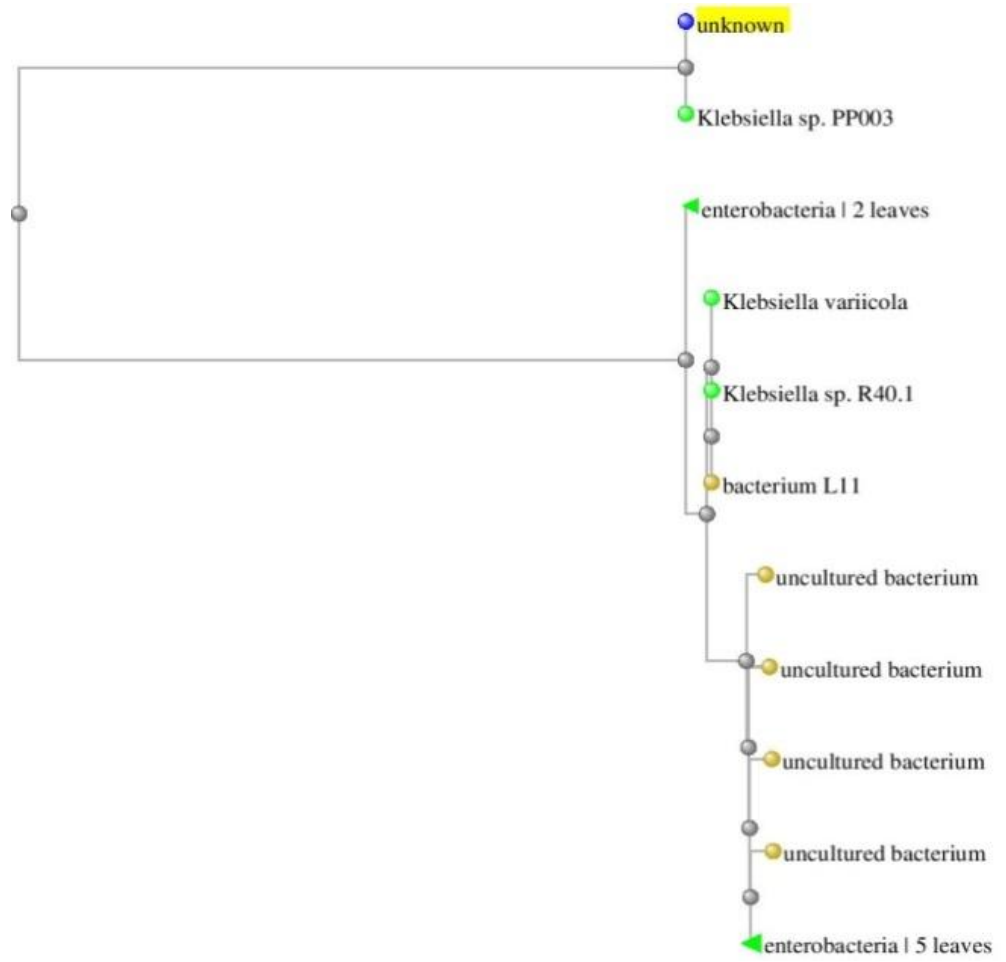

Figure 1:- Phylogenetic tree for a) E. coli, b) Enterobacter aerogenes and c)Klebsliella variicola

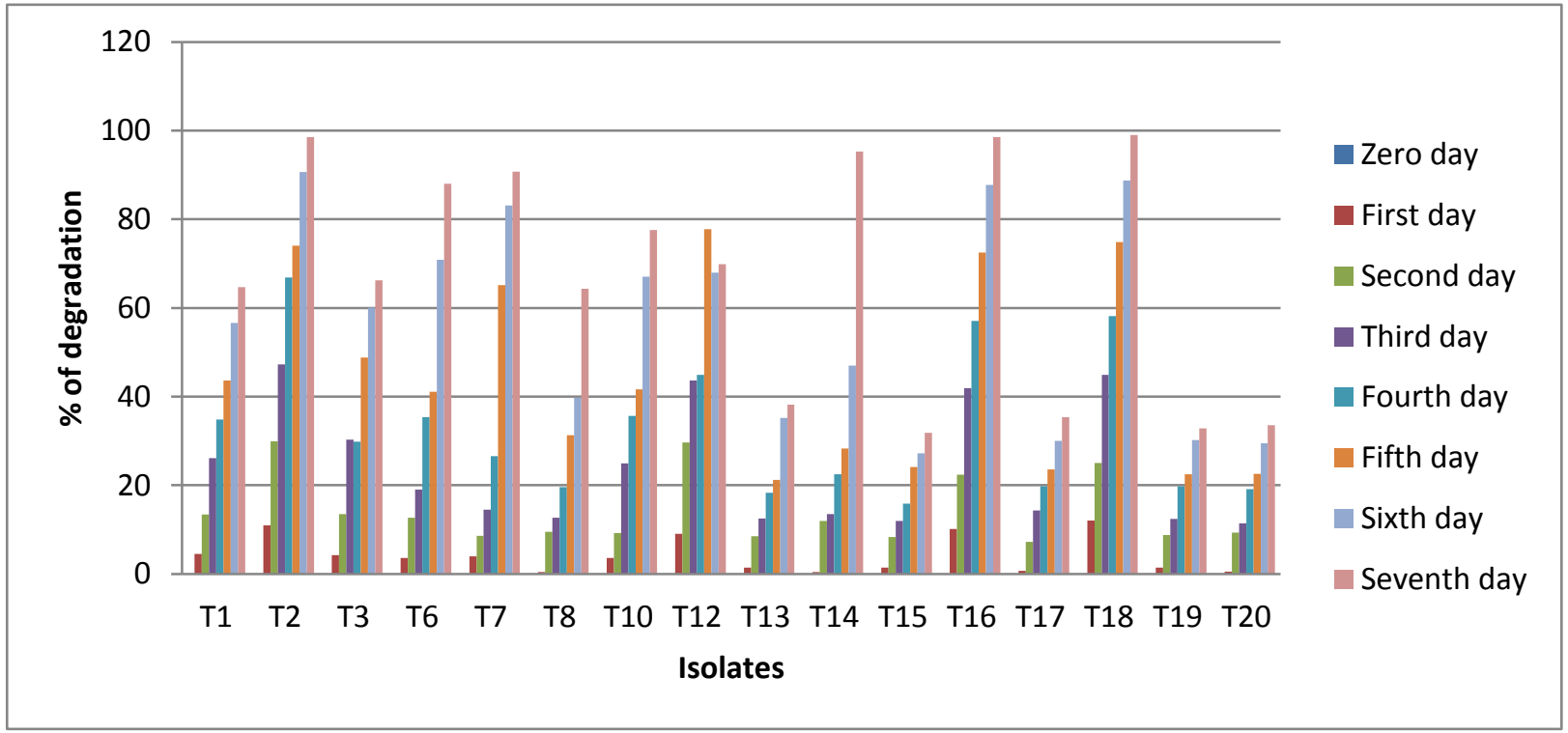

Figure 2:- Percentage of decolorization of 16 bacterial isolated from dye contaminated textile wastewater samples

\section{Effect of dye concentration:-}

The dye concentration plays a significant role in the degradation of dye by bacteria. As the concentration of dye increase the growth of organism is get decreased. At $0.01 \%$, about $98 \%$ degradation was observed by all the three isolates and gradual decrease of about $70-2 \%$ degradation was observed at various concentration of dye $0.05 \%$, $0.10 \%, 0.15 \%, 0.2 \%$. As the concentration increases the degradation by bacteria is get reduced ( figure 3 ). Subsequent increase in the substrate concentration can lead to the formation of intermediates, which absorb on the surface of the catalyst. Slow diffusion of intermediates from the catalyst surface may lead to the deactivation of active sites of the photo catalyst and the degradation efficiency was decreased. At low concentration of substrate the number of catalytic sites will not be limiting factor and the rate of degradation is proportional to the substrate concentration 
(Selvam et al., 2007). The decolourization efficiency of the dye decreases as the concentration increases may be due to the toxic effect of dye on bacterial biomass for the uptake of higher dye concentration (Saratale et al ., 2009)

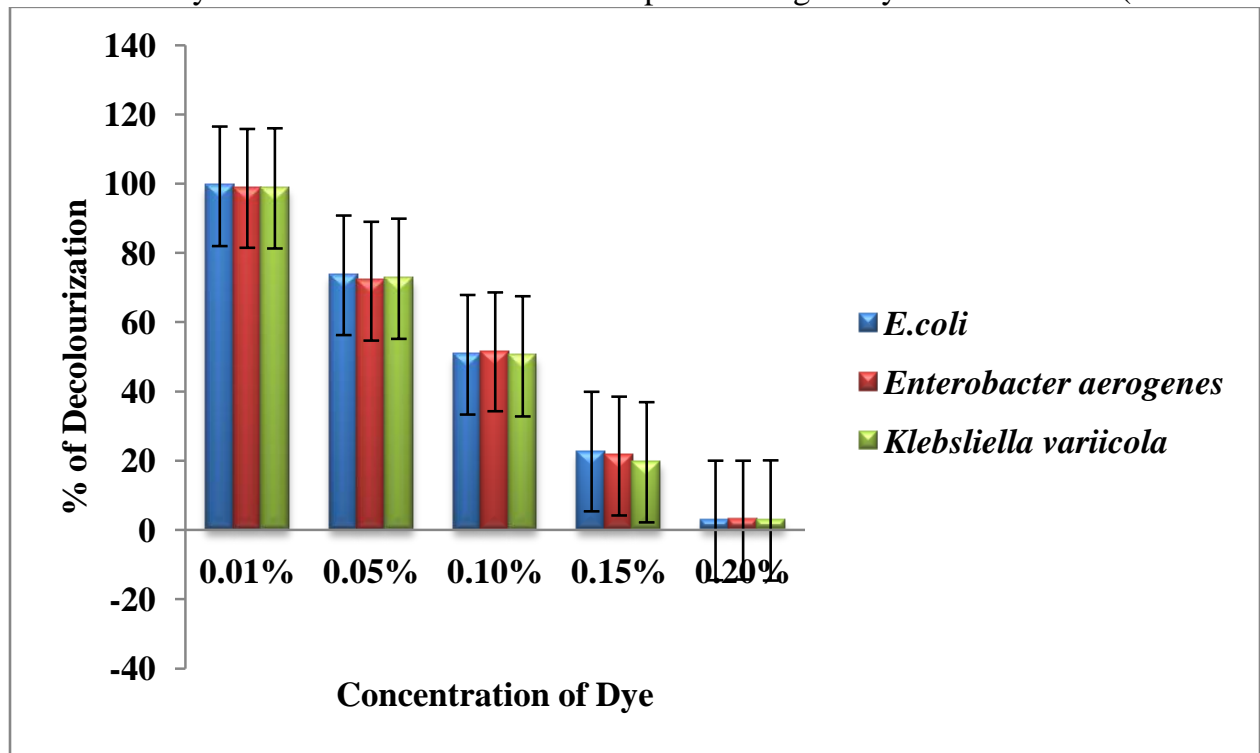

Effect of pH:-

Figure 3:- Effect of Dye Concentration (Standard error with 0.05\%)

The effect of various $\mathrm{pH}$ was performed on Red RR dye $(0.01 \%)$ degradation. As the increase of $\mathrm{pH}$ from $5-7$, the maximum decolourization was observed at $\mathrm{pH} 7$ of about $98 \%$. Further increase of $\mathrm{pH}$ at alkaline condition(pH 9), the decolourization efficiency decreased gradually (Figure 4). The transport of nutrient components across the cell membrane is carried out based on the $\mathrm{pH}$. The cell growth and enzyme production of a bacterial strain is depends upon the $\mathrm{pH}$ of the medium (Bibi et al., 2012). The optimum $\mathrm{pH}$ of the system for the decolourization is $\mathrm{pH}$ 6-8. The optimum $\mathrm{pH}$ for the decolourization is neutral $\mathrm{pH}$ or slightly alkaline $\mathrm{pH}$ value and the rate of decolourization decreases at acid and strong alkaline $\mathrm{pH}$ value ( Tamura et al ,2007)

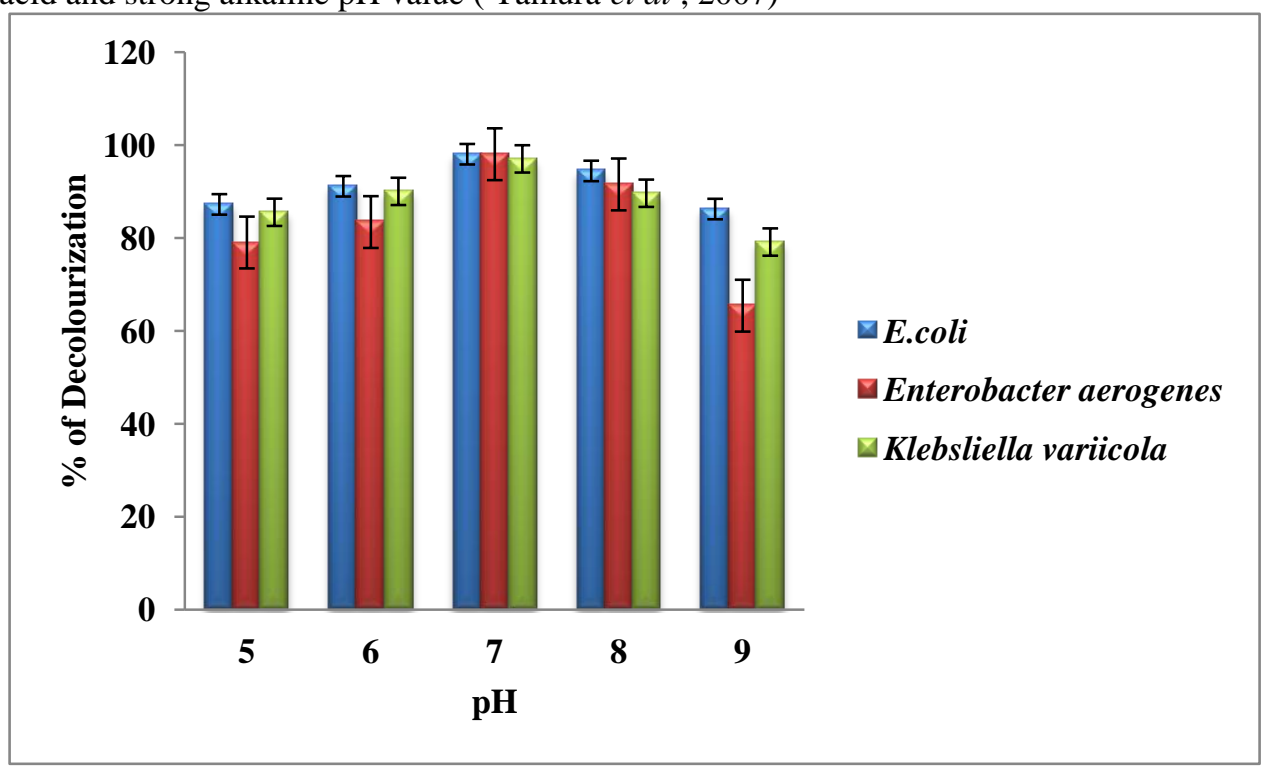

Figure 4:- Effect of $\mathrm{pH}$ at 7 (Standard error with 0.05\%)

\section{Effect of Temperature:-}

Temperature is one of the most important parameter for decolourization. At $25^{\circ} \mathrm{c}$ decolourizationwas observed of about $80 \%$ and $94 \%$ at $30^{\circ} \mathrm{C}$, as the temperature increases upto, $45^{\circ} \mathrm{C}$, the degradation efficiency decreased upto $60 \%$ due to inactivity of isolates at high temperature ( Figure 5). The efficiency of decolourization was not dependent on the temperature but there evidence that suppressed decolourizing activity at $45^{\circ} \mathrm{C}$ due to the loss of 
cell feasibility and enzyme deactivation which is essential for decolourization at high temperature (Cetin and Donmez, 2006)

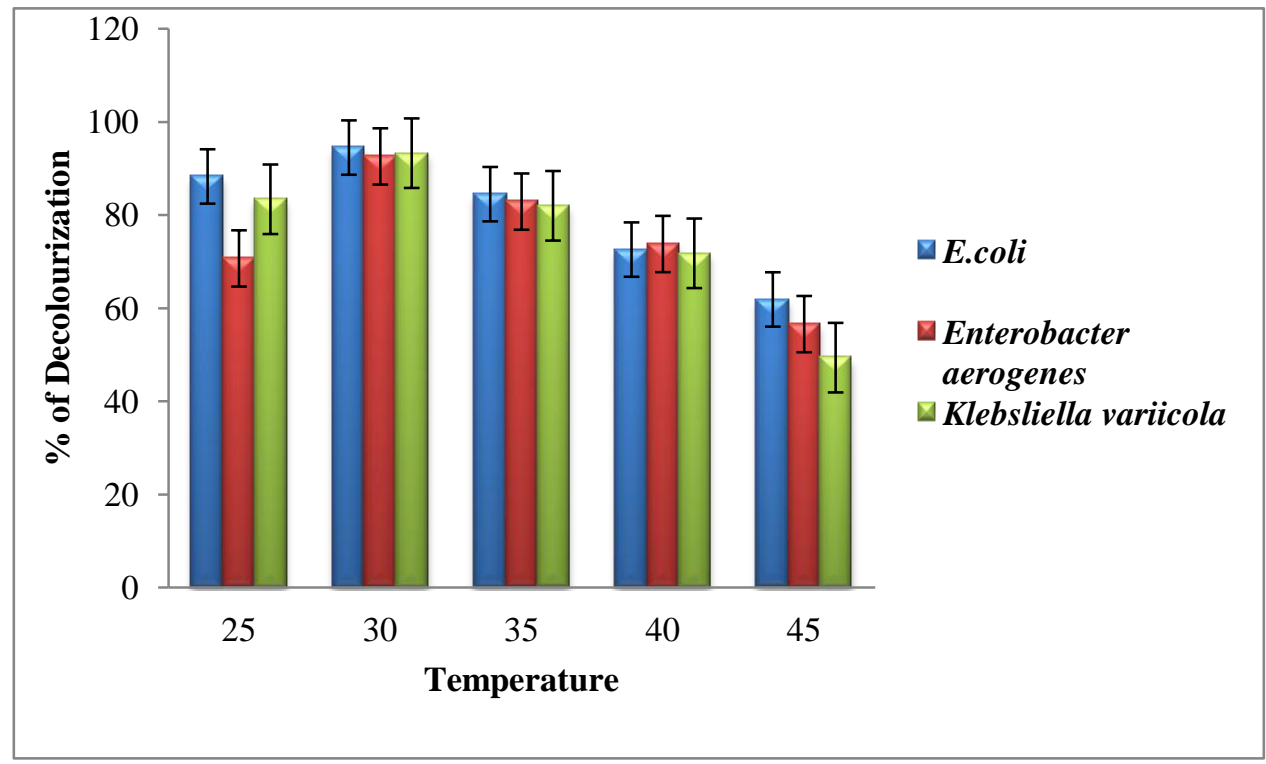

Figure 5:- Effect of Temperature (Standard error with 0.05\%)

Effect of carbon and nitrogen source:-

Carbon source such as glucose, sucrose, maltose, starch and fructose were used as a carbon source and energy source for degradation of dyes because the effluent is deficient in carbon content and biodegradation was difficult to carry out without carbon sources. Among the different carbon source, maltose shows decolourization of about $98 \%$ at concentration of $0.3 \%$ (Figure 6).In case of other carbon sources it shows degradation rate of about Carbon sources are very effective in the decolourization process because most of the organisms prefer carbon source for assimilation than using dye compound as the carbon source. (Chaube, et al., 2010).

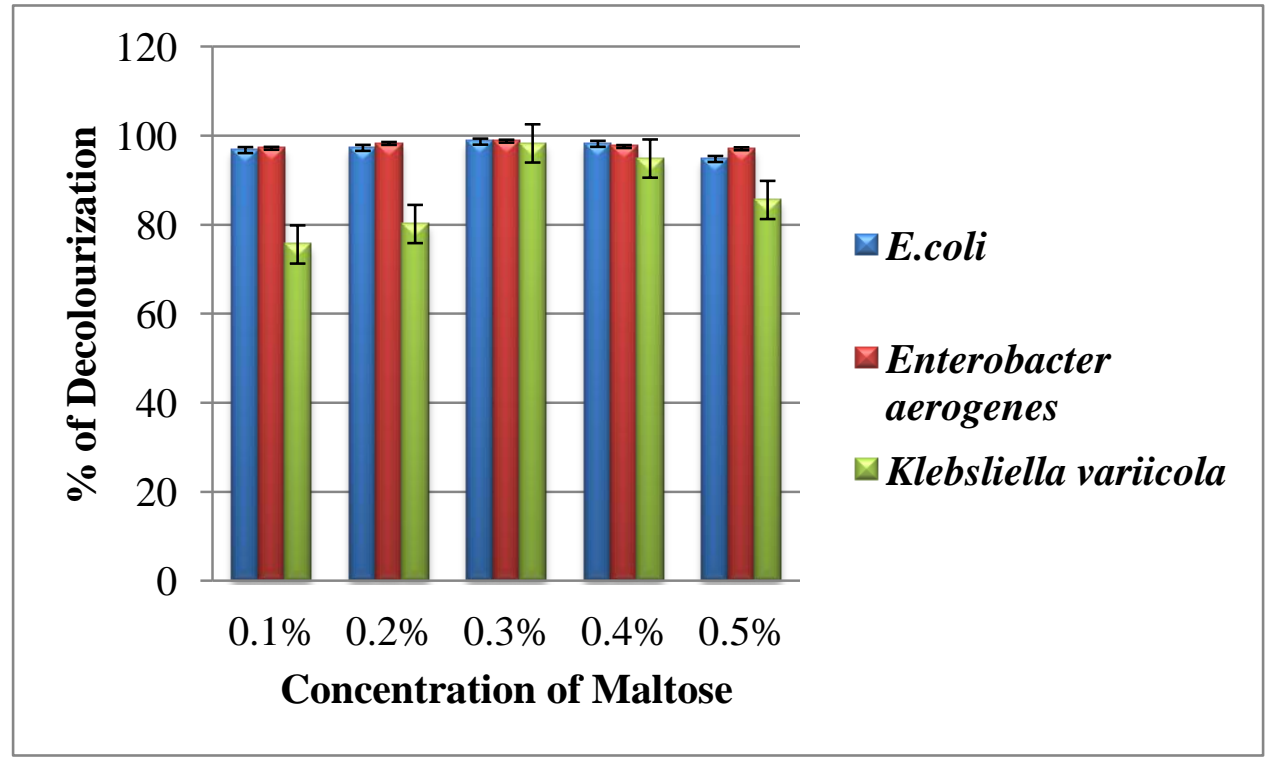

Figure 6:- Effect of maltose at various concentration (Standard error with 0.05\%)

Number of organic and inorganic compounds of Nitrogen source such as urea, peptone, dipotassium nitrate, ammonium nitrate and beef extract were used as an energy source for degradation of dyes. Among the different nitrogen source, peptone shows high degradation of about 98\%, when compared to other nitrogen sources, it shows 
only 50\% (Figure 7). In the lack of supplementary carbon and nitrogen source, bacterial strains was not capable to decolourise dye because carbon and nitrogen source is essentially for growth and decolourization (Nigam et al ., 1996)

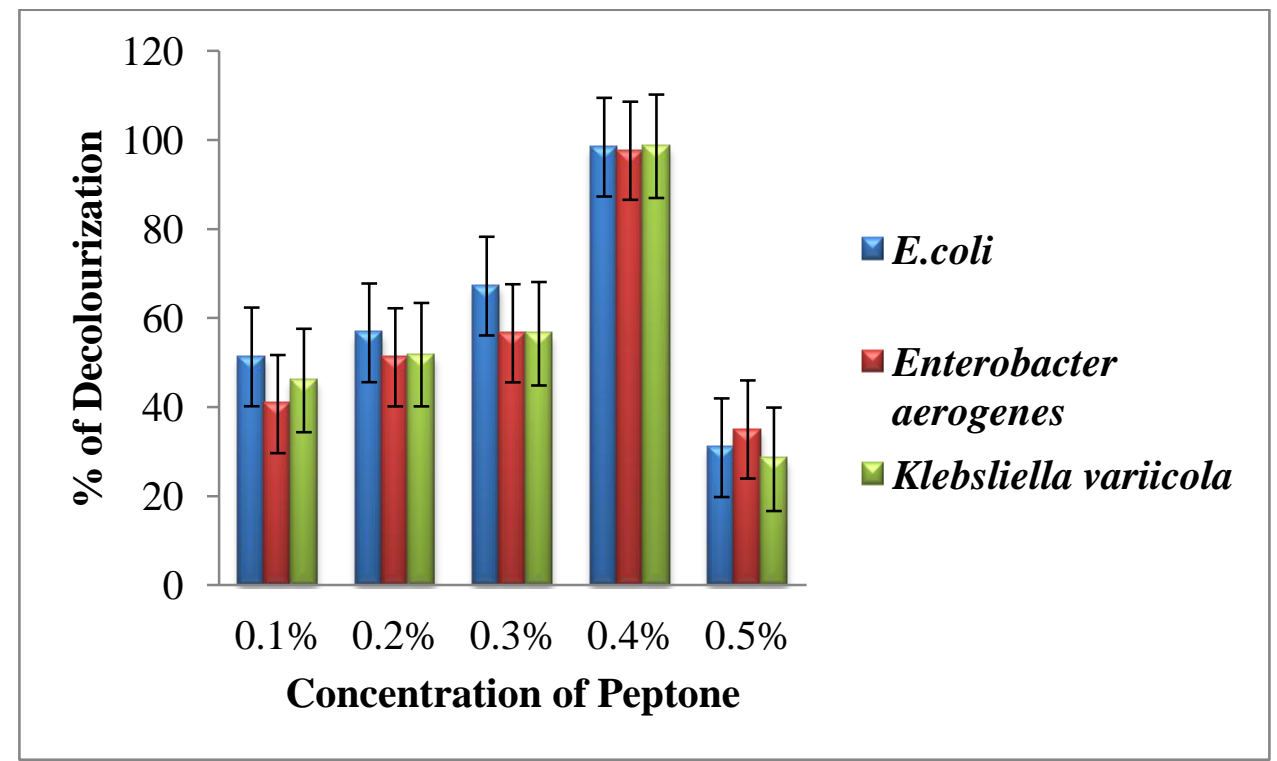

Figure 7:- Effect of peptone at various concentration (Standard error with $0.05 \%$ )

\section{Compatibility test:-}

There was no zone of inhibition around the wells after incubation of plates. The compatible nature of the bacterial cultures shows that when used in a consortium, it could degrade the complex chemical structure by symbiotic association.(Aslim et al ., 2002)( Figure 8).

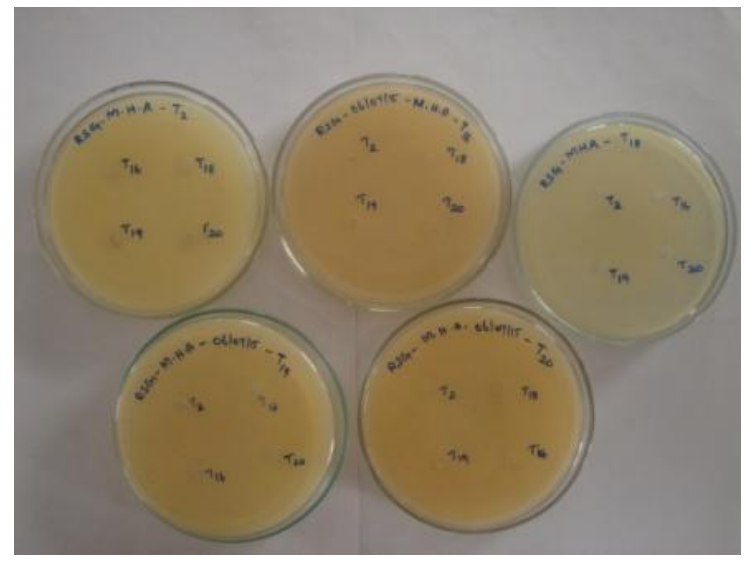

Figure 8:- Compatibility Test Mixed Consortium.

By the symbiotic association E.coli, Enterobacter aerogenes and Klebsiella variicola degrade the Red RR of about 99\% .Adaptation among microbial community towards toxic materials and recalcitrant substances is found to be very effective to improve the rate of decolourization process. The same effect on biodegradation process upon acclimation of microbial cultures was reported (Kourkoutes et al ., 2004; Baldi et al., 1997). Some mechanism for adaptations were found in microorganism and microbial population to pollutants from industries like dyes, pesticides and heavy metals. 


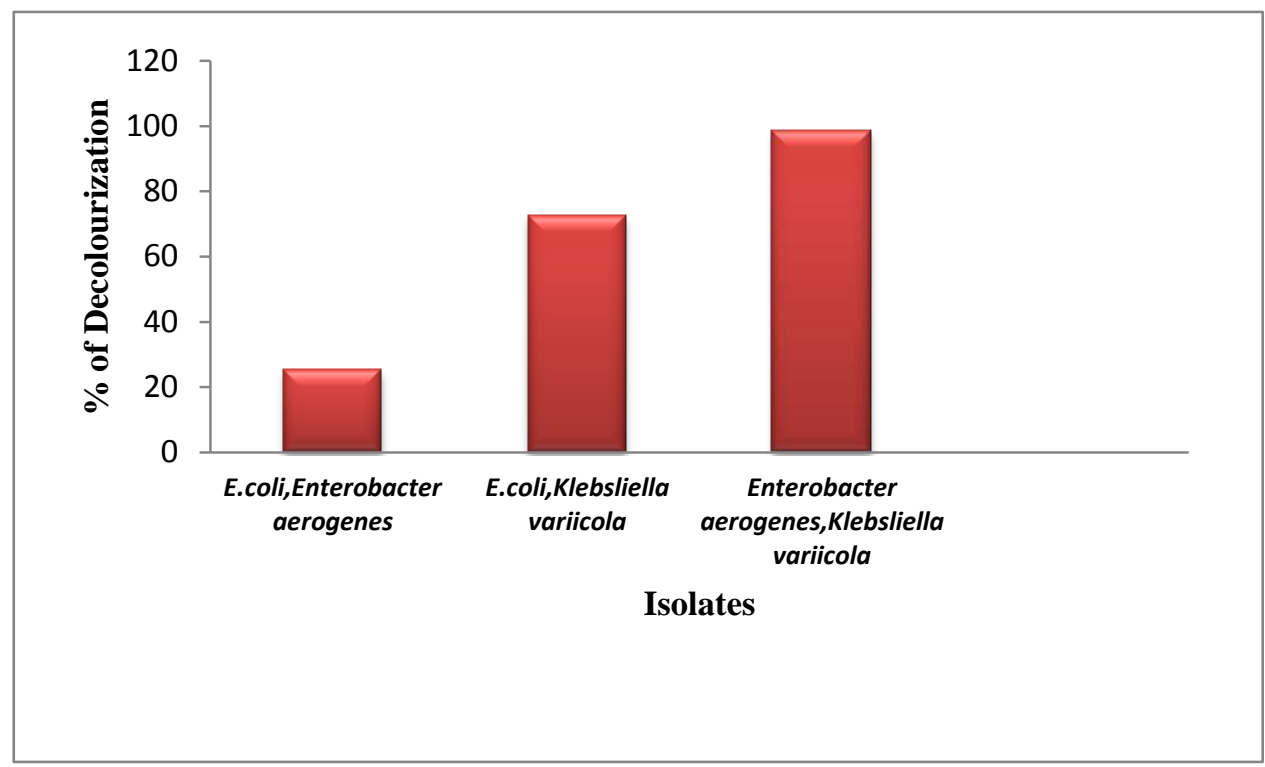

Figure 9:- Effect of biodegradation of by mixed consortium

FTIR analysis:-

FTIR results of control showed specific peaks at $3387.00 \mathrm{~cm}^{-1} \mathrm{~N}-\mathrm{H}$ stretch for Primary, secondary amines, amides; $3348.42 \mathrm{~cm}^{-1} \mathrm{~N}-\mathrm{H}$ stretch for Primary, secondary amines, amides; $2954.95 \mathrm{~cm}^{-1} \mathrm{C}-\mathrm{H}$ stretch for Alkanes; 2839.22 $\mathrm{cm}^{-1} \mathrm{O}-\mathrm{H}$ stretch for Carboxylic acids; $1273.02 \mathrm{~cm}^{-1} \mathrm{C}-\mathrm{N}$ stretch for Aromatic amines; $1056.99 \mathrm{~cm}^{-1} \mathrm{C}-\mathrm{N}$ stretch for ; Aliphatic amines; $1010.70 \mathrm{~cm}^{-1} \mathrm{C}-\mathrm{O}$ stretch for Alcohols, carboxylic acids whereas in treated sample the peaks formed are $3387.00 \mathrm{~cm}^{-1} \mathrm{~N}-\mathrm{H}$ stretch for Primary, secondary amines, amides (weak bond) $3325.28 \mathrm{~cm}^{-1} \mathrm{O}-\mathrm{H}$ stretch for Carboxylic acids;3062.96 $\mathrm{cm}^{-1}=\mathrm{C}-\mathrm{H}$ stretch for Alkenes; $2924.09 \mathrm{~cm}^{-1} \mathrm{C}-\mathrm{H}$ stretch for Alkanes; $2870.08 \mathrm{~cm}^{-1}{ }^{,} \mathrm{C}-\mathrm{H}$ stretch for Alkanes; $2630.91 \mathrm{~cm}^{-1} \mathrm{O}-\mathrm{H}$ stretch for Carboxylic acids; $2569.18 \mathrm{~cm}^{-1} \mathrm{O}-\mathrm{H}$ stretch for Carboxylic acids; $2515.18 \mathrm{~cm}^{-1} \mathrm{O}-\mathrm{H}$. Aromatic amines in the dye is carcinogenic, toxic and mutagenic. Bacterial consortium degradation doesn't produce aromatic amines under aerobic condition ( Senan and Abraham., 2004)

\section{Conclusion:-}

Due to globalization, urbanization and industrialization various environmental were emerged by the release effluent from different textile industries. Reactive dye is azo dye with different reactive groups. It is most commonly used in dyeing due to its brightness and easy colouring in clothes. The present study is based on the biodegradation of Red RR by the isolated bacterial cultures. E.coli, Enterobacter aerogenes and Klebsiella variicola degrade the Red RR effectively of about $99 \%$.

\section{Bibliography:-}

1. Aslim, B., Saglam, N., and Beyatli T., 2002. Determination of some properties of Bacillus isolated from soil. Turk. J. Biol., 26:41-48.

2. Baldi, F., Jensen, D.B., Reineke, W. Adaptation: dynamics of genes enzyme activities and populations in J.R. Wild (Ed), Perspectives in Bioremediation, vol 19, Kluwer Academic publishers, Dodrecht, 1997, PP 93-105

3. Bibi, R., M. Arshad and H.N. Asghar.Optimization of factors for accelerated biodegradation of reactive black-5 azo dyes. Int. J. Agric.Biol.2012; 14: 353-359

4. Cetin D and Donmez G (2006). Decolourization of reactive dyes by mixed cultures isolated from textile effluent under anaerobic conditions. Enzyme and Microbial Technology 38: 926-930

5. Chaube, P., Indurkar, H and Moghe, S. 2010. Biodegradation and decolourization of dye by mix consortia of bacteria and study of toxicity on Phaseolus mungo and Tritumaestivum. Asiatic J. of Biotech. 1: 45-56

6. $\mathrm{Fu}, \mathrm{Y}$ and $\mathrm{Y}$. Tiraraghavan, 2004. Removal of congo red from a aqueous solution by fungus Aspergillus niger.Advances in Environmental Research.,7: 239- 247

7. Hao, O.J., Kim, H and Chiang, P.C., 2000. Decolourization of waste water. Criterion review Environmental science technology., 30: 449- 505 
8. Lata, H., Garg, V.K., Gupta, R.K., 2007. Removal of a basic dye from aqueous solution by adsorption using Parthenium bysterophorus: an agricultural waste. Dyes and Pigment., 74: 653-658

9. Lucas M.S, Dias, A.A., Sampaio, A.,Amaral, C., Peres J.A., 2007. Degradation of textile reactive azo dye by a combined chemical- biological process: Fentons reagent- yeast. water Res., 41: 1103-1109

10. Mohana, S., Shrivastava, S., Divehi, J and Medawar, D., 2008. Response surface methodology for optimization of medium for decolorization of textile dye Direct black 22 by a novel bacterial consortium. Bioresource Technol.,99: 562-569

11. Moran C, Hall M.E, Howell R.C.,1997. Effects of sewage treatment on textile effluent. Journal of the society dyers colourists., 113: 272-274

12. Nigam , P.I.M., Banat, $M$ and Marchant, R. 1996. Decolourization of effluent from the textile industry by a microbial consortium. BiotechnolLett., 18: 117-20

13. O' Mahony, T., Guibal, E., Tobin, J.M,.2002. Reactive dye biosorption by Rhizopus arrhizus biomass. Enzyme and Microbiol Technology., 31: 456-63

14. Pazarlioglu, N.K., R.O. Urek and F. Ergun . 2005. Biodecolourization of direct blue 15 by immobilized Phanerochaete chrysosporium. Process Biochemistry., 40: 1923- 1929

15. Poots, V.J.P, MC Kay, J.J. 1976. The removal of acid dye from effluent using natural adsorbents- peat. Water research., 10:1061-6

16. Saratale R.G., Saratale, G.D. Kalyani, D.C., Chang J.S., Govindwar, S.P. 2009. Enhanced decolourization and biodegradation of textile azo dye scarlet R by using developed microbial consortium - GR. Bioresour Technol., 100: $2493-500$

17. Selvam, K., Muruganandham, M., Muthuvel,I and Swaminathan, M., 2007.The influence of inorganic oxidants and metal ions on semiconductors sensitized photodegradtion of 4 - flurophenol, Chem, Eng,J.,128: 51-57

18. Shore, J. 1995. Dyeing with reactive dyes. Adden Press, UK.

19. Tamura K, Dudley J, Nei M, Kumar S (2007). MEGA 4: Molecular evolutionary genetics analysis (MEGA) software version 40.Mol BiolEvol 24: 1596 - 1599

20. Zollinger, H.,1987.Color Chemistry- Synthesis, properties and application of organic dyes and pigments. VCH publishers, New York, 92-100 